\title{
Childhood injury deaths: rural and urban differences, Colorado 1980-8
}

\author{
Hui-Chia Hwang, Lorann Stallones, Thomas J Keefe
}

\begin{abstract}
Objectives-The purpose of this study is to describe and compare the distribution of injury deaths among rural and urban Colorado children that occurred between 1980-8.

Method-Death certificates coded E800E969 were obtained for children who were 0-14 years of age at death between 1980-8 and who were Colorado residents. Average annual rates were computed for rural and urban children, separately by gender. The 1980 census was used to compute rates. Rate ratios were calculated to summarize information related to specific external causes of deaths, contrasting rural and urban children. These differences were evaluated using $Z$ tests.
\end{abstract}

Results-Statistically significant elevated risks were found along rural children for motor vehicle injury deaths. Firearms were involved more often in rural deaths among unintentional injury deaths of children older than 4 years of age, and among homicide related deaths of children 5 years and younger. All rural children who committed suicide used a firearm.

Conclusions-Comparisons between rural and urban injury deaths provide important information that can be used to guide prevention strategies. For example, in Colorado, a child restraint law, passed in 1984, covered children under 4 years of age or under 40 pounds. It was not until 1995, however, that legislation was passed requiring restraint of children 5-16 years of age. Traditionally, rural residents are slower to accept new ideas and to alter current practices than urban residents.

(Injury Prevention 1997; 3: 35-37)

Keywords: rural/urban comparisons.

Although data have been published demonstrating differences in childhood injury mortality comparing Europe, other developed and industrialized countries, and middle income developing countries, ${ }^{12}$ little has been published related to rural and urban differences within a geographic region. This study was conducted to provide information needed in the development of injury prevention program planning in Colorado that took account of the distribution of populations in rural and in urban settings. This was done by describing and comparing the distribution of injury related deaths between 1980-8 among Colorado rural and urban children.

\section{Methods}

Data used in this study included all deaths among children under 15 years of age who died from injuries among Colorado residents between 1980-8. All deaths were coded using the International Classification of DiseasesAdapted E codes (ICDA E800-E969). Death certificate data were obtained from the Colorado Department of Health, Division of Vital Statistics. The denominators used were based on the Bureau of the Census 1980 enumeration.

A metropolitan statistical area (MSA) is defined as 'a large population nucleus together with adjacent communities which have a high degree of economic and social integration'. Areas qualify for establishment as a new MSA by containing either 'a central city of 50000 or an urban area of 50000 with a total metropolitan population of at least $100000^{\prime} .^{3}$ NonMSA counties are those that do not meet this definition. There are 10 urban counties (MSA) and 53 rural counties (non-MSA) in Colorado. Deaths were classified as rural or urban based on the county where the child was a resident at the time of death using United States census definitions of urban and rural.

Ages were grouped into five year intervals: $0-4,5-9$, and 10-14. Death rates were calculated separately by gender. Differences in rates between rural and urban children were statistically evaluated using tests based on asymptotic normality of rates. ${ }^{4}$ The ninth revision of the International Classification of Diseases-Adapted was used to classify injuries (see Appendix). Motor vehicle injuries were passenger, pedestrian, bicyclist, motorcyclist, driver, and other/unspecified. The latterother/unspecified-included animal drawn vehicles, aircraft, and watercraft, as well as unspecified position in a motor vehicle. Unintentional injuries were those not associated with motor vehicles, further classified as drowning, suffocation/aspiration, fire/burn, firearm, falls, struck by object, and all other. Intentional injuries were either homicide, according to cause, including firearms, child abuse/neglect or other, or as suicide, also according to cause, including firearms, hanging, and other.

Average annual rates were computed for boys and girls in each five year age group. Rate ratios, that is rural to urban death rates, were computed to summarize the results and facilitate comparisons. Because there were no rural deaths among black children and too few rural 
deaths among other races, only white children are represented in the analysis.

\section{Results}

A total of 1010 injury deaths occurred among white children in Colorado between 1980-8. Of these, 295 (29.2\%) occurred among children who were residents of rural counties and $715(70.8 \%)$ occurred among children who were residents of urban counties. The population distribution of children by residence was $28.3 \%$ rural and $71.7 \%$ urban. The average annual injury death rate among rural children was 20.8/100 000 and among urban children was $19.9 / 100000$.

Table 1 Mean annual injury rates/100 000 and rate ratios comparing rural and urban boys by external cause and age, Colorado 1980-8

\begin{tabular}{|c|c|c|c|c|c|c|c|c|c|}
\hline & \multicolumn{3}{|c|}{$0-4$ years } & \multicolumn{3}{|c|}{ 5-9 years } & \multicolumn{3}{|c|}{$10-14$ years } \\
\hline & $\begin{array}{l}\text { Rural } \\
\text { rate }\end{array}$ & $\begin{array}{l}\text { Urban } \\
\text { rate }\end{array}$ & Ratio & $\begin{array}{l}\text { Rural } \\
\text { rate }\end{array}$ & $\begin{array}{l}\text { Urban } \\
\text { rate }\end{array}$ & Ratio & $\begin{array}{l}\text { Rural } \\
\text { rate }\end{array}$ & $\begin{array}{l}\text { Urban } \\
\text { rate }\end{array}$ & Ratio \\
\hline 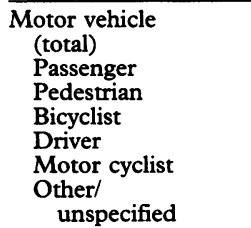 & $\begin{array}{l}16.0^{\star} \\
6.9^{\star} \\
6.9^{\star} \\
0.0 \\
0.0 \\
0.0 \\
\\
2.1\end{array}$ & $\begin{array}{l}6.6 \\
3.1 \\
2.8 \\
0.2 \\
0.3 \\
0.0 \\
\\
0.3\end{array}$ & $\begin{array}{l}2.4 \\
2.2 \\
2.5 \\
- \\
- \\
- \\
7.0\end{array}$ & $\begin{array}{l}15.3 \\
4.5^{\star} \\
4.0 \\
3.4^{\star} \\
0.0 \\
0.0 \\
\\
3.4\end{array}$ & $\begin{array}{l}5.6 \\
1.8 \\
2.4 \\
0.9 \\
0.0 \\
0.0 \\
\\
0.5\end{array}$ & $\begin{array}{l}2.7 \\
2.5 \\
1.7 \\
3.8 \\
- \\
- \\
6.8\end{array}$ & $\begin{array}{l}15.3^{\star} \\
5.5 \\
1.6 \\
2.2 \\
0.6 \\
1.6 \\
\\
3.8\end{array}$ & $\begin{array}{l}7.7 \\
3.3 \\
1.5 \\
0.8 \\
0.6 \\
0.6 \\
\\
1.0\end{array}$ & $\begin{array}{l}2.0 \\
1.7 \\
1.1 \\
2.7 \\
1.0 \\
2.7 \\
\\
3.8\end{array}$ \\
\hline $\begin{array}{l}\text { Other unintentional } \\
\text { (total) } \\
\text { Drowning } \\
\text { Suffocation/ } \\
\text { aspiration } \\
\text { Fire/burn } \\
\text { Frearm } \\
\text { Fall } \\
\text { Struck by } \\
\text { Other/unspecified }\end{array}$ & $\begin{array}{l}25.0^{\star} \\
11.2^{\star} \\
5.9 \\
2.1 \\
0.0 \\
1.6 \\
3.2 \\
1.1\end{array}$ & $\begin{array}{l}14.4 \\
5.4 \\
3.7 \\
0.8 \\
0.3 \\
0.8 \\
1.1 \\
2.5\end{array}$ & $\begin{array}{l}1.7 \\
2.1 \\
\\
1.6 \\
2.6 \\
2.0 \\
2.9 \\
0.4\end{array}$ & $\begin{array}{l}17.0 \\
5.7 \\
\\
0.6 \\
1.1 \\
3.4^{\star} \\
0.6 \\
2.8 \\
2.8\end{array}$ & $\begin{array}{l}5.6 \\
2.3 \\
\\
0.5 \\
0.2 \\
0.5 \\
0.8 \\
0.5 \\
1.1\end{array}$ & $\begin{array}{l}3.0 \\
2.5 \\
\\
1.2 \\
5.5 \\
6.8 \\
0.8 \\
5.6 \\
2.6\end{array}$ & $\begin{array}{l}14.2 \\
3.3 \\
\\
2.2 \\
0.6 \\
3.8 \\
0.6 \\
1.6 \\
2.2\end{array}$ & $\begin{array}{l}8.0 \\
1.5 \\
\\
2.4 \\
0.4 \\
1.5 \\
0.7 \\
0.6 \\
0.8\end{array}$ & $\begin{array}{l}1.7 \\
2.2 \\
\\
0.9 \\
1.5 \\
2.5 \\
0.9 \\
2.7 \\
2.8\end{array}$ \\
\hline $\begin{array}{l}\text { Homicide (total) } \\
\text { Firearm } \\
\text { Child abuse/neglect } \\
\text { Hanging } \\
\text { Other/unspecified }\end{array}$ & $\begin{array}{l}5.3 \\
1.1 \\
2.1 \\
0.5 \\
1.6\end{array}$ & $\begin{array}{l}6.1 \\
0.2 \\
1.5 \\
0.6 \\
3.8\end{array}$ & $\begin{array}{l}0.9 \\
5.5 \\
1.4 \\
0.8 \\
0.4\end{array}$ & $\begin{array}{l}0.0^{\star} \\
0.0 \\
0.0 \\
0.0 \\
0.0\end{array}$ & $\begin{array}{l}0.8 \\
0.3 \\
0.2 \\
0.0 \\
0.3\end{array}$ & $\begin{array}{l}- \\
- \\
- \\
-\end{array}$ & $\begin{array}{l}0.0^{\star} \\
0.0^{\star} \\
0.0 \\
0.0 \\
0.0\end{array}$ & $\begin{array}{l}2.2 \\
1.3 \\
0.3 \\
0.1 \\
0.6\end{array}$ & $\begin{array}{l}- \\
- \\
- \\
-\end{array}$ \\
\hline
\end{tabular}

${ }^{\star} \mathrm{p}<0.05$ comparing rural to urban rates based on $\mathrm{Z}$ test; a 'dash' denotes zero in numerator or denominator.

Table 2 Mean annual injury rates 100000 and rate ratios comparing rural and urban girls by external cause and age, Colorado 1980-8

\begin{tabular}{|c|c|c|c|c|c|c|c|c|c|}
\hline & \multicolumn{3}{|c|}{$0-4$ years } & \multicolumn{3}{|c|}{ 5-9 years } & \multicolumn{3}{|c|}{ 10-14 years } \\
\hline & $\begin{array}{l}\text { Rural } \\
\text { rate }\end{array}$ & $\begin{array}{l}\text { Urban } \\
\text { rate }\end{array}$ & Ratio & $\begin{array}{l}\text { Rural } \\
\text { rate }\end{array}$ & $\begin{array}{l}\text { Urban } \\
\text { rate }\end{array}$ & Ratio & $\begin{array}{l}\text { Rural } \\
\text { rate }\end{array}$ & $\begin{array}{l}\text { Urban } \\
\text { rate }\end{array}$ & Ratio \\
\hline $\begin{array}{l}\text { Motor vehicle (total) } \\
\text { Passenger } \\
\text { Pedestrian } \\
\text { Bicyclist } \\
\text { Driver } \\
\text { Motor cyclist } \\
\text { Other/unspecified }\end{array}$ & $\begin{array}{l}8.5 \\
4.0 \\
2.3 \\
0.6 \\
0.0 \\
0.0 \\
1.7\end{array}$ & $\begin{array}{l}5.3 \\
3.2 \\
1.8 \\
0.0 \\
0.0 \\
0.0 \\
0.3\end{array}$ & $\begin{array}{l}1.6 \\
1.3 \\
1.3 \\
- \\
- \\
\overline{5} .7\end{array}$ & $\begin{array}{l}7.9 \\
5.5 \\
0.0 \\
1.8 \\
0.0 \\
0.0 \\
0.6\end{array}$ & $\begin{array}{l}3.8 \\
2.1 \\
1.4 \\
0.2 \\
0.0 \\
0.0 \\
0.2\end{array}$ & $\begin{array}{l}2.1 \\
2.6 \\
\overline{9} \\
\overline{-} .0 \\
\overline{3} .0\end{array}$ & $\begin{array}{l}9.7 \\
3.4 \\
1.7 \\
0.6 \\
1.1 \\
0.0 \\
2.9\end{array}$ & $\begin{array}{l}5.1 \\
2.3 \\
1.9 \\
0.3 \\
0.3 \\
0.0 \\
0.3\end{array}$ & $\begin{array}{l}1.9 \\
1.5 \\
0.9 \\
2.0 \\
3.7 \\
- \\
9.7\end{array}$ \\
\hline $\begin{array}{l}\text { Other unintentional } \\
\text { (total) } \\
\text { Drowning } \\
\text { Suffocation/ } \\
\text { aspiration } \\
\text { Fire/burn } \\
\text { Firearm } \\
\text { Fall } \\
\text { Struck by } \\
\text { Other/unspecified }\end{array}$ & $\begin{array}{l}15.3^{\star} \\
6.2 \\
4.0 \\
2.3 \\
0.0 \\
0.6 \\
0.6 \\
1.7\end{array}$ & $\begin{array}{l}8.8 \\
2.6 \\
\\
2.9 \\
1.4 \\
0.0 \\
1.0 \\
0.5 \\
0.5\end{array}$ & $\begin{array}{l}1.7 \\
2.4 \\
\\
1.4 \\
1.6 \\
-0.6 \\
1.2 \\
3.4\end{array}$ & $\begin{array}{l}0.6 \\
0.0^{\star} \\
0.2 \\
0.0^{\star} \\
0.0 \\
0.0 \\
0.0 \\
0.0\end{array}$ & $\begin{array}{l}2.1 \\
0.8 \\
\\
0.0 \\
0.8 \\
0.3 \\
0.2 \\
0.0 \\
0.0\end{array}$ & $\begin{array}{l}0.3 \\
- \\
- \\
- \\
- \\
- \\
-\end{array}$ & $\begin{array}{l}1.1 \\
0.0 \\
\\
0.0 \\
0.0 \\
1.1 \\
0.0 \\
0.0 \\
0.0\end{array}$ & $\begin{array}{l}2.0 \\
0.0 \\
\\
0.2 \\
0.4 \\
0.4 \\
0.4 \\
0.0 \\
0.6\end{array}$ & $\begin{array}{l}- \\
\overline{2} .8 \\
\overline{-} \\
-\end{array}$ \\
\hline $\begin{array}{l}\text { Homicide (total) } \\
\text { Firearm } \\
\text { Child abuse/neglect } \\
\text { Hanging } \\
\text { Other/unspecified }\end{array}$ & $\begin{array}{l}4.0 \\
0.0 \\
2.3 \\
0.6 \\
1.1\end{array}$ & $\begin{array}{l}3.2 \\
0.2 \\
0.8 \\
1.0 \\
1.3\end{array}$ & $\begin{array}{l}1.3 \\
- \\
2.9 \\
0.6 \\
0.9\end{array}$ & $\begin{array}{l}1.3 \\
1.2 \\
0.0 \\
0.0 \\
0.0\end{array}$ & $\begin{array}{l}1.3 \\
0.6 \\
0.0 \\
0.2 \\
0.5\end{array}$ & $\begin{array}{l}1.0 \\
2.0 \\
- \\
- \\
-\end{array}$ & $\begin{array}{l}0.0^{\star} \\
0.0 \\
0.0 \\
0.0 \\
0.0\end{array}$ & $\begin{array}{l}1.0 \\
0.3 \\
0.0 \\
0.3 \\
0.4\end{array}$ & $\begin{array}{l}- \\
- \\
- \\
-\end{array}$ \\
\hline
\end{tabular}

${ }^{\star} \mathrm{p}<0.05$ comparing rural to urban rates based on $\mathrm{Z}$ test; a 'dash' denotes zero in numerator or denominator.
The average annual rates for boys and girls comparing external causes of injury deaths between rural and urban children are summarized in table 1 (boys) and table 2 (girls). Moto vehicle injury deaths and unintentional injury? deaths were generally higher among ruraR children, but only deaths related to motos vehicles were significantly elevated. Homicide and suicide rates were lower among rura? children, with the homicide death rates being significantly lower.

Among boys, the rural motor vehicle death? rates were significantly higher for passengers and bicyclists aged 5-9 and for pedestrians $0-\overrightarrow{0}$ 4 years. Unintentional injury rates significantly elevated for rural boys included drowning $(0-\omega$ 4 years) and firearm related deaths (5-8 years).

Among the girls, the rural motor vehicle related deaths were only significantly highef among 5-9 year old bicyclists. None of the unintentional injury death rates was significantly different between rural and urban girls and there were few unintentional or homicide deaths among rural girls aged 5 years and older.

Due to the low frequency of suicide deaths in the total population, no rates or rate ratios are presented. All suicide deaths among rurat children were associated with firearms, com? pared with only $51 \%$ of those among urbaro children. These deaths involved boys olde? than 4 and girls over 9 years of age. Firearmp related suicides among boys 10-14 years old were $14 \%$ higher among those in rural than in urban counties $(p<0.05)$ and the rate ratio for firearm related deaths among girls $10-14$ years old was 0.98 .

\section{Discussion}

Rural and urban children live in differens environments that may affect their exposure to the risk of fatal injury. Generally, rural areas differ from urban areas in: (1) the highee speeds permitted on roads; (2) the number of streets/highways; (3) poorer conditions of roads; (4) steep and unprotected embank $\frac{7}{O}$ ments; (5) delays in communication; (6) longer. distances in travel; (7) less availability of emergency medical services, resulting in slower response times; and (8) limited access tô trauma care. ${ }^{5}$ In urban areas, risk character $\frac{\omega}{0}$ istics may include: (1) increased drug abuse (2) heavier traffic; and (3) limited space fo playgrounds. ${ }^{5}$ There are also important differ $\stackrel{5}{?}$ ences in familiarity with firearms.

Higher passenger related motor vehicle rate $\bar{\phi}$ were evident in rural areas for all age groups but the greatest difference was in the age्ष groups 5-9 years for both boys and girlso Attitudes and practices related to use of chilक restraints in motor vehicles may be different between rural and urban parents. That mav lead to increased motor vehicle death rates among rural children.

Death certificates can only provide an incomplete picture of injury risk. In Colorado, deaths are certified by a coroner, not by a medical examiner, and there may be systematic 
bias in reporting of intention. In rural areas, individuals tend to be known to the coroner, whereas in urban settings families are not likely to be friends or neighbors of the coroner. For this reason, this information needs to be interpreted with caution. The rates presented here are, however, quite similar to those published for Europe and other industrialized countries. ${ }^{1}$ In addition, the rate differences are similar in magnitude to those reported between industrialized countries and the middle income developing countries by cause.

Recently, a review of successful injury prevention programs was published. ${ }^{6}$ Many of those reported to be effective were applicable in urban areas but may have less success or applicability in rural areas. Examples of this include programs related to the design of city streets that separate children from traffic, the use of cycle helmets (which, while effective in many circumstances, are likely to be less effective in high velocity impact situations), the use of protective barriers around swimming pools, and domestic ponds. ${ }^{6}$ In rural areas, children are not likely to be playing on city streets, may ride their bicycles on rural highways resulting in high speed collisions, and drownings tend to occur in natural bodies of water or irrigation ditches, where fencing may not be a feasible alternative. Thus, many of the interventions proposed would not address the situations encountered in rural settings.

In addition, rural residents have been characterized as resistant to change, traditional, focused on personal and informal community networks, concrete thinkers, and self reliant. ${ }^{7}$ These characteristics are in contrast to those of urban residents who are said to be more reliant on the scientific method, embracing change, establishing formal and transient relationships, abstract thinkers, and believers in the authority of the state. ${ }^{7}$ Such differences make it even more important to tailor prevention programs to the target population. Data obtained from areas other than the local arena may not provide convincing evidence for rural residents to change practices or attitudes toward injury prevention. This paper provides evidence that injury risks between rural and urban children differ, and that further work is needed to elaborate on these differences.

Research support for this project came from Colorado State University, Diversity Career Enhancement Award from the Equal Opportunity Council, from the Department of Environmental Health and College of Veterinary Medicine and Biomedical Sciences as start-up funds for Dr Stallones. The work comes from Hui-Chia Hwang's master's thesis awarded in 1990. This publication was supported by grant number R49/ CCR811509 from the Centers for Disease Control and Prevention, National Center for Injury Prevention and Control. Its contents are solely the responsibility of the authors and not necessarily represent the official views of the Centers for Disease Control and Prevention, National Center for Injury Prevention and Control.

\section{Appendix: E codes used in classification of} injuries

Motor vehicle injuries

Passenger E812.1; E812.3; E815.1; E816.1; E818.1; E819.1; E825.1

Pedestrian E805.2; E814.7; E822.7

Driver E812.0; E816.0; E818.0;

Bicyclist $\quad$ E813.6; E826.1

Motorcyclist E812.2; E815.2; E821.2

Other/ E810.9; E812.9; E816.9; unspecified E819.9; E821.8; E821.9; E825.9; E827-E848

Other unintentional injuries

Drowning E910

Suffocation/

aspiration E911-E913

Fire/burn E890-E899, E924

Firearm E922

Falls E880-E888

Struck by object

All other

E916-E918

E850-E869; E900-E909; E919; E925; E929; E920.9; E928.9

Homicide

Firearms E965

Child abuse/ neglect

E967; E968.4

Other E962-E963; E968.0;

Suicide

Firearms E968.9; E964; E969

Hanging

E955

Other

E953

E950-E952; E957-E959

1 Taket A. Accident mortality in children, adolescents and young adults. World Health Stat $Q, 1986 ; 39: 232-56$. Rivara FP. Traumatic deaths of children in the United States: currently available prevention strategies. Pediatrics 1985; 75: 456-62.

3 Bureau of the Census, US Department of Commerce. 1980 Census of population and housing unit counts. Washington, DC: Department of Commerce, 1984.

4 Fleiss JL. Statistical methods for rates and proportions. 2nd Ed. New York, NY: John Wiley and Sons, 1981.

5 Baker SP, O'Neill B, Karpf RS. The injury fact book. Lexington, MA: Heath Press, 1984.

6 Dowswell T, Towner EML, Simpson G, Jarvis SN. Preventing childhood unintentional injuries-what works? A literature review. Injury Prevention 1996; 2: 140-9. 7 Levy M. The structure of society. Princeton, NJ: Princeton
University Press, 1952 . 